DOI

\title{
ЧУТЛИВІСТЬ УРОПАТОГЕННИХ ШТАМІВ ЕSCHЕRICHIA COLI ДО ПРЕПАРАTIВ АМІНОПЕНІЦИЛІНОВОГО ТА НІТРОФУРАНОВОГО РЯДІВ У 2015 РОЦІ
}

\section{๑я. О. Михалко}

\section{ДВНЗ «Ужгородський національний університет», м. Ужгород}

РЕЗЮМЕ. У роботі наведено результати дослідження частоти резистентності та чутливості уропатогенних штамів E. coli до антибактеріальних препаратів амінопеніцилінового та нітрофуранового рядів. Показано, що при емпіричному лікуванні інфекції сечовивідних шляхів серед досліджених похідних пеніциліну найдоцільніше використовувати ампіциліну сульбактам, а серед похідних нітрофурану - нітрофурантоїн.

КЛЮчОВІ СлОВА: інфекція сечовивідних шляхів, Escherichia coli, антибіотики, амінопеніцилінові антибіотики, похідні нітрофурану.

Вступ. Інфекції сечовивідних шляхів (ІСШ) є однією з найчастіших причин звернень пацієнтів до лікаря загальної практики з приводу бактеріальнозумовлених захворювань. Найефективнішою тактикою лікування даної категорії хворих $\epsilon$ призначення антибактеріальних (АБ) препаратів [1]. При цьому АБ призначають, як правило, емпірично. До препаратів вибору, поряд з представниками інших груп, належать також препарати амінопеніцилінового ряду та похідні нітрофурану [2, 3]. Водночас дедалі частіше з'являються повідомлення про зростаючий рівень резистентності основних збудників ІСШ до амінопеніцилінових препаратів та порівняно високу чутливість до нітрофуранових АБ [4-6]. Однак патерни чутливості та резистентності мікроорганізмів до АБ різняться від країни до країни. Саме тому для оптимізації емпіричної терапії ІСШ важливим $€$ дослідження регіонального спектра антибіотикочутливості основних збудників даної інфекції та врахування цього при емпіричному лікуванні ІСШ.

Мета дослідження-вивчення особливостей регіональної чутливості уропатогенних штамів E. coli до АБ амінопеніцилінового та нітрофуранового рядів у пацієнтів з ІСШ у 2015 році.

Матеріал і методи дослідження. У ході роботи було проведено аналіз результатів бактеріологічного дослідження 64 зразків сечі дорослих пацієнтів, які лікувалися з приводу ІСШ, зумов- леної E. coli, протягом 2015 року в лікувальних закладах м. Ужгород. Ідентифікацію мікроорганізмів проводили за стандартними методиками на класичних диференціально-діагностичних середовищах. Визначення чутливості збудників до АБ амінопеніцилінового (ампіцилін, ампіцилін/ сульбактам та амоксицилін/клавуланова кислота) та нітрофуранового (фуразидин, фуразолідон та нітрофурантоїн) рядів проводили за стандартною методикою з використанням диск-дифузійного методу у бактеріологічних відділеннях клінікодіагностичних лабораторій Центральної міської клінічної лікарні м. Ужгород та ДЗ «Відділкова клінічна лікарня станції Ужгород" ДТГО “Львівська залізниця». Статистичну обробку результатів проводили за допомогою пакета прикладних програм Statistica 8.0 (StatSoft, США).

Результати та їх обговорення. Вивчення профілю антибіотикорезистентності уропатогенних штамів E. coli до АБ амінопеніцилінового ряду показало, що найвищим цей показник був для амоксициліну, захищеного клавулановою кислотою 84,09 \% випадків, тоді як найрідше траплялася резистентність до ампіциліну/сульбактаму - 29,55 \% випадків. До ампіциліну, не захищеного сульбактамом, резистентність також була високою (69,57 \%). Чутливість виділених штамів E. coli до вказаних АБ становила $9,09 \%, 47,73 \%$ та 13,04 \% відповідно (табл. 1).

Таблиця 1. Резистентність E. coli, виділеної у пацієнтів з ІСШ, до антибіотиків амінопеніцилінового та нітрофуранового рядів (\%)

\begin{tabular}{|l|c|c|c|}
\hline \multicolumn{1}{|c|}{ Антибіотик } & $\mathrm{S}$ & $\mathrm{I}$ & $\mathrm{R}$ \\
\hline Ампіцилін/сульбактам, $\mathrm{n=52}$ & 47,73 & 22,73 & 29,55 \\
\hline Ампіцилін, $\mathrm{n=63}$ & 13,04 & 17,39 & 69,57 \\
\hline Амоксицилін/клавуланова кислота, $\mathrm{n=55}$ & 9,09 & 6,82 & 84,09 \\
\hline Фуразидин, $\mathrm{n}=57$ & 47,06 & 35,29 & 17,65 \\
\hline Фуразолідон, $\mathrm{n}=58$ & 74,42 & 4,65 & 20,93 \\
\hline Нітрофурантоїн, $\mathrm{n}=54$ & 70,27 & 5,41 & 24,32 \\
\hline
\end{tabular}

Примітка: 1) S- чутливість; 2) I- помірна резистентність; 3) R- резистентність; 4) n-кількість досліджених зразків сечі. 
Огляди літератури, оригінальні дослідження, погляд на проблему

На особливу увагу заслуговують мікроорганізми з помірною резистентністю (ПР) до досліджуваних препаратів, оскільки їх використання у середньотерапевтичних дозах $\epsilon$ малоефективним з одного боку та сприяє зростанню антибіотикорезистентності в загальній популяції - з іншого. Серед досліджених у ході роботи пеніцилінових АБ, ПP E. coli найчастіше траплялася до ампіциліну/ сульбактаму (22,73\%), дещо рідше - до ампіциліну $(17,39 \%)$ та амоксициліну клавуланату $(6,82 \%)$.

Серед досліджених похідних нітрофурану найвищий рівень резистентності E. coli був до нітрофурантоїну (24,32 \%), дещо нижчим - до фуразолідону (20,93 \%), найнижчим - до фуразидину (17,65 \%). В той же час, рівень чутливості вказаного збудника ІСШ був найвищим до фуразолідону $(74,42 \%)$, дещо нижчим - до нітрофурантоїну $(70,27 \%)$, найнижчим - до фуразидину $(47,06 \%)$. Тобто, незважаючи на найнижчий рівень резистентності E. coli до фуразидину, чутливість даного збудника до нього теж виявилася найнижчою. Така на перший погляд невідповідність пов'язана з високою частотою ПР до цього препарату, яка

\section{ЛITEPATYPA}

1. Guidelines on Urological Infections [Electronic resourse] / M. Grabe, R. Bartoletti, T. E. Bjerklund Johansen [et at.] // European Association of Urology. Electronic data. - 2015. - 86 p. - Access mode: World Wide Web: https://uroweb.org/guideline/urologicalinfections/?type=archive (viewed on March 03, 2016). Title from the screen.

2. Уніфікований клінічний протокол медичної допомоги. Гострий неускладнений цистит у жінок. Первинна медична допомога [Електронний ресурс] / О. М. Гиріна, С. П. Пасєчніков, Д. Д. Іванов [та ін.] // Наказ МОЗ України № 816 від 23.11.2011 р. - Режим доступу: httр:// www.moz.gov.ua/ua/portal/dn_20111123_816.html (дата звернення 03.04.2016р.). - Назва з екрана.

3. Колесник М. О. Протокол надання медичної допомоги хворим на пієлонефрит. [Електронний ресурс] / М. О. Колесник, І. О. Дудар, Н. М. Степанова // На- становила 35,29 \%. На противагу цьому, рівень ПР до нітрофурантоїну та фуразолідону був дуже незначним (5,41 та 4,65 \% відповідно). Варто зазначити, що, не зважаючи на порівняно низький показник резистентності та високий рівень чутливості E. coli до фуразолідону in vitro, його не рекомендовано застосовувати при лікуванні ІСШ, оскільки при його використанні в терапевтичних дозах не вдається домогтися концентрації препарату в сечі, достатньої для елімінації збудника ICШ.

Висновки. Встановлено високий рівень резистентності уропатогенних штамів E. coli до всіх досліджених у ході роботи препаратів. При необхідності призначення АБ амінопеніцилінового ряду перевагу слід надавати ампіцилін/сульбактаму та уникати призначення амоксициліну клавуланату. Із досліджених препаратів похідних нітрофурану доцільно призначати нітрофурантоїн.

Перспективи подальших досліджень. У подальшому планується постійно проводити моніторинг рівня резистентності збудників ІСШ до АБ на регіональному рівні.

каз МОЗ України № 593 від 12.12.2004 р. - Електронні дані.-Режим доступу: http://www.moz.gov.ua/ua/portal/ dn_20041212_593.html (дата звернення 03.04.2016 р.). Назва з екрана.

4. Antimicrobial susceptibilities of Escherichia coli isolates as agents of community-acquired urinary tract infection (2008-2014) / N. Yılmaz, N. Ağuş, A. Bayram [et al.] // Turk. J. Urol. - 2016. - Vol. 42, № 1. - P. 32-36.

5. Betrán A. Evaluation of antibiotic resistance of Escherichia coli in urinary tract infections in Primary Care Barbastro Sector (Huesca) / A. Betrán, A.M. Cortés, C. López // Rev. Esp. Quimioter. - 2015. - Vol. 28, № 5. P. 263-266.

6. High prevalence of multidrug-resistance uropathogenic Escherichia coli strains, Isfahan, Iran / R. Dehbanipour, S. Rastaghi, M. Sedighi [et al.] // J. Nat. Sci. Biol. Med. - 2016. - Vol. 7, № 1. - P. 22-26.

\title{
SUSCEPTIBILITY OF THE UROPATHOGENIC ESCHERICHIA COLI STRAINS TO THE AMINOPENICILLINS AND NITROFURANS ANTIMICROBIALS IN 2015
}

○Ya. O. Mykhalko

\author{
Uzhhorod National University, Uzhhorod
}

SUMMARY. The paper presents the results of the study of the uropathogenic E. coli strains resistance and susceptibility rates to aminopenicillins and nitrofurans antimicrobials. It is shown that among the examined derivatives of penicillin in the empirical treatment of urinary tract infection the most appropriate is to use ampicillin/sulbactam, and among nitrofuran derivatives - nitrofurantoin.

KEY WORDS: urinary tract infection, Escherichia coli, antibiotics, aminopenicillins, nitrofurans. 